\title{
CONCEPTUAL FUNDAMENTALS OF DEVELOPMENT OF THE FOOD SECURITY SYSTEM
}

\author{
Inna Irtyshcheva', Maryna Ponomarova², Iryna Dolzhykova ${ }^{3}$
}

\begin{abstract}
The paper highlights the system of food security of the state. The purpose of the article is to study food security of Ukraine and identify preconditions for forming the system of its provision. The subject-matter of the study is the theoretical and practical aspects of providing food security in the country. In the process of the study, the following methods were used: dialectical - to reveal regularities and factors of the food security system, system analysis - to identify the essence of food security of the country, graphical analysis - for a schematic representation of generalized theoretical and practical results of the research, logical generalization of the results to substantiate the basic preconditions for forming a system for ensuring food security of the country. The stable system of ensuring food security of the population, the development of the agro-industrial complex and the food industry are important factors in improving the country's economic welfare. Key problems in ensuring the food security of Ukraine are analysed, among them are: low level of real incomes of the majority of the population; reduction in the share of small and medium businesses; low competitiveness of agriculture and food industry; insufficiently developed infrastructure of the food market; rising unemployment; increase in grain export volumes; deterioration of agricultural land quality; environmental pollution; the level of urbanization of the population. Main preconditions for forming the food security system are identified and substantiated: creation of favourable institutional environment that requires completion of the land reform in Ukraine; increasing the efficiency of agricultural land use; expanding the tools of state support for agricultural production; stimulating the development of crop and livestock industry; expansion of integration and technological links between agricultural producers and food industry enterprises. Based on the results obtained, the author determined the factors and conditions of the food security system.
\end{abstract}

Key words: food security, development, food security system.

JEL Classification: B22, L52, Q18

\section{Introduction}

The stable and complete food supply to the population, the development of the agro-industrial complex and the food industry are important factors in improving the country's economic welfare and strengthening its national security. According to realities, the internal and external position of Ukraine in 2017 is determined by a complex set of factors that bear the threat and risks of deepening crisis phenomena and also the possibility to enter the main path of national development. Among the main risks to the food security of Ukraine remain: insufficient state support for the agro-industrial complex, low technical and technological level of national production of food products in comparison with leading world exporters, weakening of participation of small and medium business in agricultural and food production, etc. Moreover, the low profitability of agro-industrial enterprises makes them unattractive for investors, who could contribute to raising the material and technical base and productivity of agricultural production in general. In such conditions, an undoubtedly important task is to further study food security problems and substantiate the basic prerequisites, factors of its provision, which determined the relevance of the above topic and its practical importance.

In the period of transformation of the economy of Ukraine based on market relations, considerable attention was paid to research on food security issues in the country as a whole. Issues of food security were studied in works by foreign scientists such as V. Ahaiev, L. Abalkin, I. Bohdanov, A. Bohomolov, Z. Ilina, B. Kumakhov, M. Mazoyer, W. Liefert, M. Tracy,

\footnotetext{
Corresponding author:

${ }^{1}$ Admiral Makarov National University of Shipbuilding, Ukraine.

E-mail: innauamd@gmail.com

ORCID: https://orcid.org/0000-0002-7025-9857

${ }^{2}$ Kharkiv National Agrarian University named after V.V. Dokuchaev, Ukraine.

E-mail: univerms@ukr.net

${ }^{3}$ Kharkiv National Agrarian University named after V.V. Dokuchaev, Ukraine.

E-mail: lapo4kamari@gmail.com
} 
E. Reinert and others. A wide range of domestic scientists is engaged in covering issues of ensuring food security of Ukraine, among them should be noted: P. Borshchevskyi, O. Hudzynskyi, O. Hoichuk, B. Danylyshyn, M. Dolishnii, S. Dorohuntsov, R. Ivanukh, A. Lysetskyi, I. Lukinov, M. Palamarchuk, M. Pistun, D. Preiher, P. Sabluk, M. Khorunzhyi, O. Shpychak, L. Cherniuk, M. Chumachenko, V. Yurchyshyn, and others. In their works, they studied theoretical and methodological aspects of ensuring food security and its assessment. However, appreciating the results achieved, a number of underdeveloped issues regarding the preconditions and factors for ensuring food security in Ukraine can be distinguished.

The concept of food security, which closely correlates with the welfare of the population, logically requires a permanent study of key components. Solving the global food supply problem requires local approaches taking into account the regional peculiarities of economic development. In the context of European integration processes of Ukraine, the need arises to adapt national standards of food and food security to the European Union's standards and also to coordinate organizational processes of agricultural production within the economic development of regions.

\section{Essence and features of food security}

One of the main areas for ensuring national security of the country, a means of preserving its sovereignty and independence, the essential condition for the implementation of strategic national priorities for guaranteeing high living standards is the country's food security.

Food security is an important component of the national security of the country and as an economic category is characterized by the level of guaranteed constant access of the population to food to an extent that would ensure the reproduction and development of vital needs of individuals. According to the Draft Law of Ukraine "On Food Security of Ukraine", food security is such socio-economic and environmental condition in the state, in which all its citizens are stably and guaranteedly provided with food in the volume necessary and sufficient for physical and social development of the person, health of the population of Ukraine (Postanova Verkhovnoji Rady Ukrajiny Pro pryjnjattja za osnovu proektu Zakonu Ukrajiny pro prodovoljchu bezpeku Ukrajiny). Herewith, food security indicators are: quantitative and qualitative characteristics of the state, dynamics, and perspectives of physical and economic availability of foods for all social and demographical groups of the population, level and structure of their consumption, quality and safety of food, stability and degree of independence of the internal food market, development level of the agricultural sector and related industries of the economy, as well as the efficiency of the use of agricultural natural resource potential, etc. (Postanova Verkhovnoji Rady Ukrajiny Pro pryjnjattja za osnovu proektu Zakonu Ukrajiny pro prodovoljchu bezpeku Ukrajiny).

In the opinion of the scientist O. M. Chechel, "food security" can be defined as a state of protection of the food interests of a person, society, state from external and internal threats, which allows ensuring the functioning of people, economy, and industry, providing all sectors of the population with sufficient quality products, and controlling crisis situations (2000, p. 74).

Prominent domestic scientists P. T. Sabluk (2009, p. 5) and O. V. Paskhaver (2014, p. 9) noted that ensuring food security depends on the ability to food self-production and, therefore, the most informative is the indicator of the share of own food production in consumption, the limit value of which should be $75-80 \%$.

It should be pointed out that for an individual, food security is one of the guarantees of the real right to life, and not only declared in the Constitution of Ukraine and other laws and regulations. And for society, food security is the most important guarantee of the sociopolitical stability of the harmonious development of all its strata. The functioning of any country considers food security as a general economic indicator, which value increases along with the deepening crisis of government and economy. Therefore, food security is one of the acutest problems of national security.

Therefore, according to the author, the concept of "food security" has three essential aspects: economic, political, and environmental. Food security as an economic category determines target parameters of functioning and sustainable development of the economic system and characterizes food sovereignty, guaranteed product availability for the population, quality and environmental cleanliness of food products.

It should be noted that food security factors play both positive and negative roles for ensuring the country's food security; let us distinguish main groups of these factors: economic, political, environmental, and also natural and climatic (Figure 1). Negative influence is assessed by natural disasters, military actions, and environmental pollution.

Among the characteristic main factors of ensuring food security are the following: investment support for the agro-industrial complex by the state and business, state support and development of transport and logistics, economic welfare of the population, the legal and legislative framework of Ukraine. These factors are complementary and interdependent in the country's food security.

Since food resources are formed in the process of agro-industrial production, this very sector of the national economy serves as a basis for ensuring food security of the country. At present, Ukraine has the Agricultural Sector Development Strategy (for the period up to 2020) but the corresponding Program for 


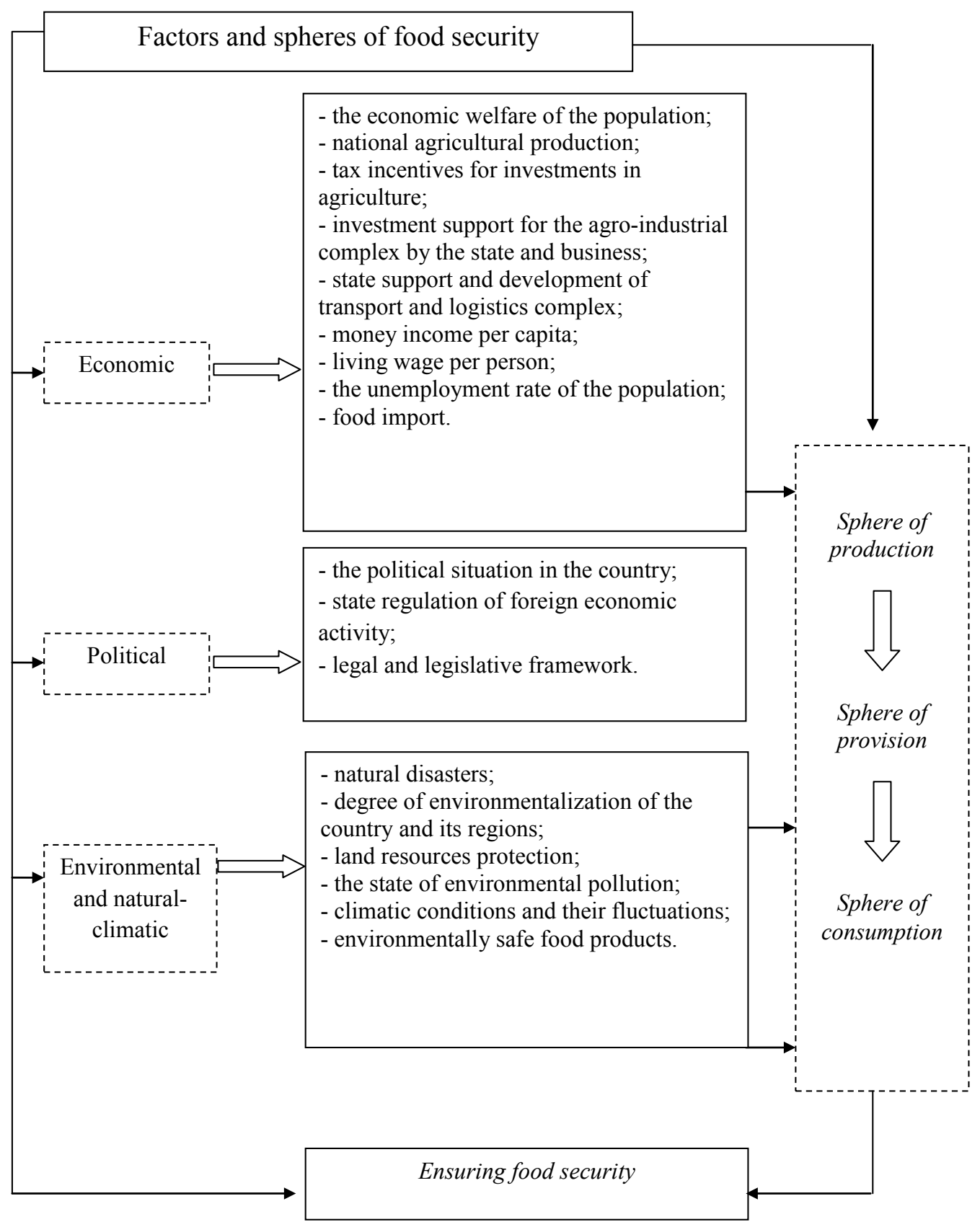

Figure 1. Influence of factors on the food security system

its implementation has not been developed. Moreover, the work of the agro-industrial complex is greatly complicated by the impossibility of a stable economic activity in the occupied territories of the Donbas and in the Autonomous Republic of Crimea, the loss of control over land users' compliance with the requirements for the land protection and rational use on agricultural lands. So as a result of hostilities, the planted area for agricultural crops has decreased significantly. In particular, in the Donetsk region in 2016, 989.5 thousand hectares were allocated for basic crops, which is $30.9 \%$ less than in 2013 (1 431.8 thousand hectares) (Derzhavna sluzhba statystyky Ukrainy). In the Luhansk region in 2016, the planted area for agricultural crops has reduced by $23.7 \%$ (from 1030.4 thousand hectares to 786.3 thousand hectares, respectively) compared to 2013. Only at the initial stage of the ATO, the estimated losses of the agrarian sector in the Donetsk region amounted to 0.5 billion UAH, Luhansk - 1.2 billion UAH (Chorna knygha Kremlja. Vijna Rosiji proty Ukrajiny, 2015).

Deterioration of the quality of agricultural lands also should be noted. The absence of clear prospects for the development of agriculture in the territories adjacent to the conflict zone demotivates the intensification of agricultural production, inducing economic entities to use only natural soil fertility. If on average in Ukraine $96 \mathrm{~kg}$ of 
mineral fertilizers was added per 1 hectare of sown area, farms of Donetsk and Luhansk regions in 2016, 62 and $56 \mathrm{~kg}$ (in nutrients) of mineral fertilizers were introduced per 1 hectare of sown area, which are the lowest indicators in Ukraine (Derzhavna sluzhba statystyky Ukrainy).

Studies show that despite the incompleteness of the land reform, permanent changes in public regulation of the agricultural business, which predetermine maintaining the raw material orientation of agricultural production, the agricultural sector of the economy has strong growth potential. The main tasks of the state development policy in the agricultural sector as an important precondition for ensuring the country's food security should become the following:

- create favourable institutional environment that requires the completion of the land reform in Ukraine; legislative regulation of the issue of agricultural land circulation, requiring the completion of public discussion and submission to the Verkhovna Rada of Ukraine of the Draft Law of Ukraine "On Market Turnover of Agricultural Land"; ordering the land cadastre of Ukraine;

- increase the efficiency of agricultural land use that requires the creation of a stable market mechanism for land relations' regulation, improvement of economic and legal relations of land ownership; provision of conservation of degraded and low-yield land; extension of the list of tools for fiscal stimulation of land users to increase the area of pasture and hayfields; provision of modernization, reconstruction, and technical re-equipment of reclamation systems;

- expand tools of state support for agricultural production and liberalize conditions for its obtaining, which requires: development of new instruments of subsidization and compensatory payments for the production of plant and livestock products, which does not contradict the requirements of the World Trade Organization; simplifying the conditions for agricultural producers for obtaining preferential credit resources and ensuring transparency in tender commissions' decisionmaking; improvement of the distribution of household allowances in support of the agricultural sector; - stimulating the development of crop and livestock industry by encouraging agricultural producers to use intensive technologies in crop production; the expansion of integration and technological links among agricultural producers and food industry enterprises to create clusters of food products with a high degree of preparedness; stimulating the modernization of the fisheries industry in order to reduce the import dependence of Ukraine on this type of food products.

Consequently, promoting the growth of performance indicators of the agro-sector through the production and sale of products with a greater share of added value, increasing the efficiency of using the resources involved in production, especially land, introducing effective mechanisms for supporting agribusiness with simultaneous large-scale deregulation and abolition of bureaucratic restrictions will contribute to ensuring an adequate level of food security of Ukraine.

In the current economic conditions, a crisis in food and processing industry of many enterprises is observed, which is determined by: depreciation of basic production assets, low level of food production technology. Therefore, issues of innovative development of the food industry as a part of the agro-industrial sector are important and relevant in overcoming the negative outcomes of the crisis (Teorija i praktyka dijaljnosti pidpryjemstv: monoghrafija. Innovacijyj rozvytok pidpryjemstv kharchovoji sfery ekonomiky reghionu, 2017). Equally important is to create conditions for the renewal and modernization of food and processing industry enterprises through the technical re-equipment on the basis of resource-saving technologies.

Today, there is a low level of food security of the population in Ukraine. It is worth noting that an important aspect of solving this problem is the need of food quality control, the absence of which should be considered the main reason for the deterioration of indicators of life of the population.

Among the problems facing Ukraine on the way towards forming a system of food security are the following:

- low level of real incomes of the majority of the population;

- reduction in the share of small and medium businesses; - low competitiveness of agriculture and food industry; - the market is provided mainly by imported products; - insufficiently developed infrastructure of the food market;

- rising unemployment;

- increase in grain export volumes;

- state of the infrastructure of agriculture;

- deterioration of agricultural land quality;

- environmental pollution;

- the level of urbanization of the population.

An important factor of the food security system of Ukraine is export of agricultural raw materials and food resources, as the formation of export potential simultaneously contributes to the increase of the efficiency of use of the agrarian sector as a whole. Also, a necessary component for today is the introduction and development of scientifically grounded food export strategy. It should be noted that such a strategy should be aimed at supporting the development of export competitive industries in accordance with international standards, which involve the use of a large list of support instruments such as direct and indirect subsidizing of exporters, lending.

In 2016, there was an increase in the volumes of harvesting main crops due to the increase in agricultural crop yield. As a result, Ukraine, in the marketing year of $2015 / 16$, ranked 7 th in the world in terms of wheat yield. Production increase in agricultural crops for grain and oilseeds groups has allowed a significant increase in the shipment of agricultural products for export, which in 
2016 amounted to 15.2 billion USD, which is 0.7 billion USD more than in 2015 (Analitychna dopovidj do Shhorichnogho Poslannja Prezydenta Ukrajiny do Verkhovnoji Rady Ukrajiny "Pro vnutrishnje ta zovnishnje stanovyshhe Ukrajiny v 2017 roci”).

\section{Global Food Security Index}

Starting from 2012, at the level of the economy of the world countries, the Global Food Security Index (hereinafter - GFSI) is determined that defines the financial and physical availability of food for the population of an individual country, taking into account the qualitative characteristics of food products and their safety for human health. The methodology for determining the GFSI was proposed by a group of British researchers, the Economist Intelligence Unit, of The Economist, with the support and cooperation with the American multinational company DuPont. The Global Food Security Index, developed by the Economist Intelligence Unit, explores key aspects of financial and physical availability of food, as well as food quality and safety in 109 countries. This index takes into account more than 28 food safety characteristics, which make up three main groups of factors:

1. Affordability.

2. Availability.

3. Quality and safety (Ghlobaljnyj indeks prodovoljchoji bezpeky).

An analysis of the Global Food Security Index makes it possible to identify trends in the gradual decline in food availability indicators (Figure 2).

According to this index, food security is assessed as a condition in which the population has such access as physical, social, and economic to food (in sufficient quantity and sufficient nutritional value) that meets the needs of their diet for a healthy livelihood. The main purpose of the study is to identify the most and least vulnerable countries in terms of food security by such categories as financial and physical affordability, as well as the quality and safety of food products (Ghlobaljnyj indeks prodovoljchoji bezpeky).

As can be seen from Fig. 2, every year the food security index of Ukraine is deteriorating. In 2017, the country ranked 63rd out of 113 countries, gaining 54.1 points, compared with 2014 decreased in the ranking by 10 positions. Such changes are caused by the facts: high corruption level, gross domestic product per capita, an insufficient amount of financing of scientific researches and new developments in the agrarian sector and risks of political instability, entrepreneurs who are engaged in agriculture are not provided with cheap loans, political instability in the country.

In 2017, the three groups of GFSI factors are complemented by a fourth, reflecting the state of natural resources and their resilience (Natural Resources \& Resilience). On the basis of the numerical values of the Global Food Security Index, a ranking of countries around the world is formed by the level of food security (Table 1).

Among the 113 countries included in the food security ranking in 2016, Ukraine ranked 59th with a food security index of 56.1. In 2012, Ukraine ranked 46th with a food security index of 57.8. Thus, despite the increase in the rating of Ukraine, it is possible to state that the index of food security is falling. Comparing the components of the Global Food Security Index for Ukraine and, on average, for all other countries (Figure 3), one can state that Ukraine lags behind according to the component of the assessment of the availability of food products.

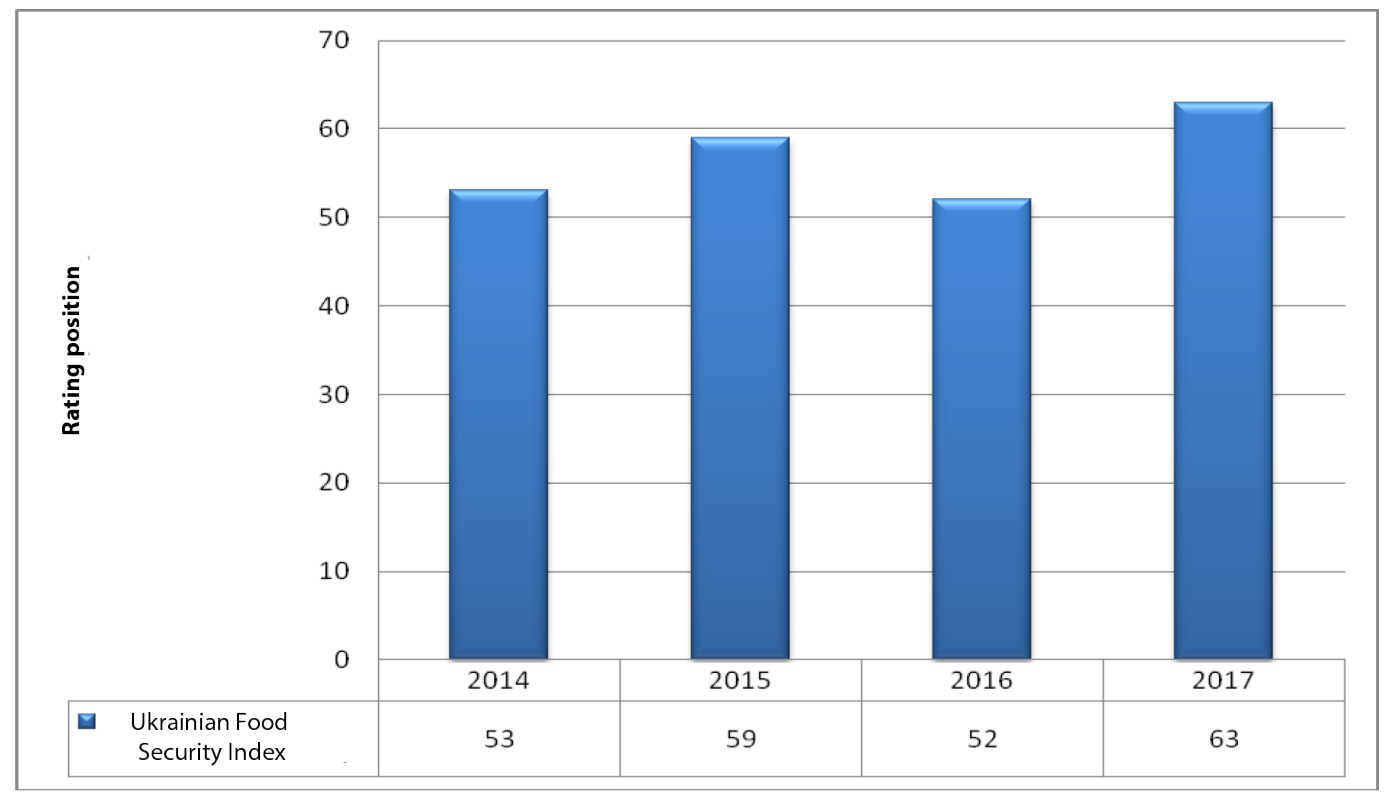

Figure 2. Ukrainian Food Security Index 
Table 1

The ranking of countries by the level of food security (Global Food Security Index) for 2016

\begin{tabular}{|c|c|c|c|c|c|}
\hline Ranking & Country & GFSI & Ranking & Country & GFSI \\
\hline 1. & USA & 89.0 & 31 & Hungary & 71.4 \\
\hline 2. & Singapore & 88.2 & 32 & Slovakia & 70.7 \\
\hline 3. & Ireland & 85.4 & 33 & Uruguay & 69.4 \\
\hline 4. & Austria & 85.1 & 34 & Malaysia & 69.0 \\
\hline 5. & Netherlands & 85.0 & 35 & Mexico & 68.7 \\
\hline 6. & Switzerland & 84.4 & 36 & Brazil & 67.4 \\
\hline 7. & Canada & 84.2 & 37 & Argentina & 67.1 \\
\hline 8. & Germany & 83.9 & 38 & Costa Rica & 66.9 \\
\hline 9. & Australia & 83.8 & 39 & Turkey & 66.0 \\
\hline 10. & France & 83.8 & 40 & Panama & 65.4 \\
\hline 11. & Norway & 83.8 & 41 & South Africa & 64.5 \\
\hline 12. & Sweden & 82.9 & 42 & China & 64.2 \\
\hline 13. & New Zealand & 82.8 & 43 & Russia & 63.8 \\
\hline 14. & Denmark & 82.6 & 44 & Belarus & 63.5 \\
\hline 15. & United Kingdom & 81,6 & 45 & Romania & 63.3 \\
\hline 16. & Portugal & 80.5 & 46 & Botswana & 63.1 \\
\hline 17. & Finland & 79.9 & 47 & Egypt & 61.8 \\
\hline 18. & Belgium & 79.5 & 48 & Venezuela & 61.7 \\
\hline 19. & Israel & 78.9 & 49 & Serbia & 61.5 \\
\hline 20. & Spain & 78.9 & 50 & Bulgaria & 61.0 \\
\hline 21. & Japan & 77.4 & 51 & Tunisia & 60.1 \\
\hline 22. & Italy & 77.0 & 52 & Thailand & 60.0 \\
\hline 23. & United Arab Emirates & 75.6 & 53 & Colombia & 59.6 \\
\hline 24. & Kuwait & 75.5 & 54 & Peru & 58.6 \\
\hline 25. & Czech Republic & 74.9 & 55 & Jordan & 58.5 \\
\hline 26. & South Korea & 74.8 & 56 & Dominican Republic & 56.8 \\
\hline 27. & Chile & 74.3 & 57 & Kazakhstan & 56.8 \\
\hline 28. & Poland & 74.2 & 58 & Azerbaijan & 56.6 \\
\hline 29. & Greece & 73.5 & 59 & Ukraine & 56.1 \\
\hline 30. & Saudi Arabia & 72.8 & 60 & Ecuador & 56.0 \\
\hline
\end{tabular}

Source: Ghlobaljnyj indeks prodovoljchoji bezpeky

The dynamics of the components of the food security index of Ukraine shows that from 2013 Ukraine lags behind the average for the second component of the GFSI as regards to estimating the availability of food

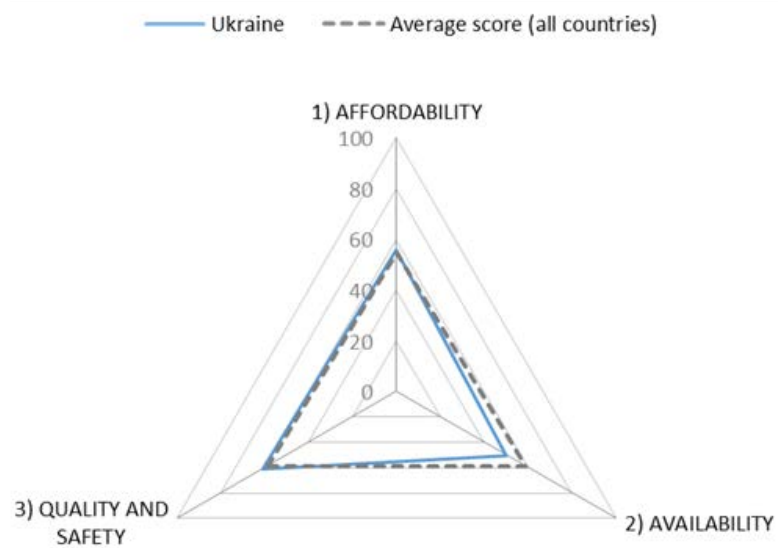

Figure 3. Estimation of Ukrainian food security index components for the first half of $\mathbf{2 0 1 7}$

Source: Ghlobaljnyj indeks prodovoljchoji bezpeky products. Estimates of the components of GFSI are presented in Table 2.

At the beginning of 2017, Ukraine lags behind the average for the first two components of the GFSI: affordability (-1.6); availability of food products $(-3,2)$. That causes a significant lagging of Ukraine in the rating of food security. In 2017, Ukraine moves in the ranking of food security to four positions down. The deterioration of the food security situation in Ukraine takes place over an increase in the share of households' expenditures on food, supply problems, and significant food losses.

The state of natural resources of Ukraine and their level of resilience (Natural Resources \& Resilience) also affect the level of food security. The assessment of the fourth component of GFSI for Ukraine (Figure 4) shows significant deviations from the mean values.

From the viewpoint of sustainable development paradigm, the state of the water and land resources and the demographic situation in Ukraine need special attention to ensure food security of Ukraine. After all, the food industry is inextricably linked with agricultural 
Vol. 5, No. 2, 2019

Baltic Journal of Economic Studies

Table 2

Comparative estimation of component values of Ukrainian GFSI with average values for the first half of 2017

\begin{tabular}{|c|c|c|c|c|}
\hline Characteristics & Score & $\Delta$ & Rank & $\begin{array}{l}\text { Average score } \\
\text { (all countries) }\end{array}$ \\
\hline OVERALL & 54,1 & $-2,1$ & 63 & 57,3 \\
\hline 1) AFFORDABILITY & 55,7 & $-1,6$ & 59 & 54,8 \\
\hline 2) AVAILABILITY & 50,2 & $-3,2$ & $=78$ & 59,0 \\
\hline 3) QUALITY AND SAFETY & 61,0 & 0,0 & 51 & 58,7 \\
\hline 1.1) Food consumption as a share of household expenditure & 42,5 & $-7,2$ & 80 & 58,6 \\
\hline 1.2). Proportion of population under global poverty line & 99,9 & 0,0 & 32 & 73,0 \\
\hline 1.3) Gross domestic product per capita (US\$ PPP) & 5,3 & $+0,1$ & 68 & 14,5 \\
\hline 1.4) Agricultural import tariffs & 86,4 & 0,0 & 17 & 76,4 \\
\hline 1.5) Presence of food safety net programmes & 75,0 & 0,0 & 44 & 65,5 \\
\hline 1.6) Access to financing for farmers & 50,0 & 0,0 & 59 & 61,3 \\
\hline 2.1) Sufficiency of supply & 51,2 & $-26,2$ & 58 & 56,5 \\
\hline 2.2) Public expenditure on agricultural R\&D & 12,5 & $+12,5$ & 32 & 15,0 \\
\hline 2.3) Agricultural infrastructure & 50,9 & 0,0 & $=62$ & 57,6 \\
\hline 2.4) Volatility of agricultural production & 83,6 & $+5,7$ & 81 & 86,2 \\
\hline 2.5) Political stability risk & 23,5 & $+1,3$ & 93 & 46,8 \\
\hline 2.6) Corruption & 0,0 & 0,0 & 90 & 37,4 \\
\hline 2.7) Urban absorption capacity & 57,7 & $+12,4$ & 100 & 66,6 \\
\hline 2.8) Food loss & 90,4 & $-1,8$ & 45 & 84,9 \\
\hline 3.1) Diet diversification & 67,9 & 0,0 & 40 & 56,4 \\
\hline 3.2) Nutritional standards & 34,6 & 0,0 & $=101$ & 79,1 \\
\hline 3.3) Micronutrient availability & 52,0 & 0,0 & 46 & 43,9 \\
\hline 3.4) Protein quality & 54,1 & 0,0 & 47 & 49,4 \\
\hline 3.5) Food safety & 96,8 & 0,0 & 51 & 80,5 \\
\hline
\end{tabular}

Source: Ghlobaljnyj indeks prodovoljchoji bezpeky

production, which involves the use of water and land resources. And without the use of human capital, it is impossible to develop any kind of activity.

The threat to Ukraine's food security is the state of environmental pollution caused by significant volumes of industrial emissions and discharges, which adversely affects the state of soils, reservoirs, and airspace. In addition, attention needs to be paid to preserving forests, which play a very important role in improving the environmental situation.

In order to solve Ukraine's food security issue, it is also necessary to draw attention to a considerable level of population urbanization. The outflow of the rural population affects the insufficient level of labour supply of agricultural production, which in turn affects the work of the food industry.

\section{Conclusions}

Problems of food security are a part of the system of socio-economic development of the country, which involves the search for directions and mechanisms for resolving conflicts and contradictions, disproportions and imbalances that have global, national-state character. In the current economic conditions, solving the tasks of ensuring food security at the international or national level is possible only on the basis of determining the

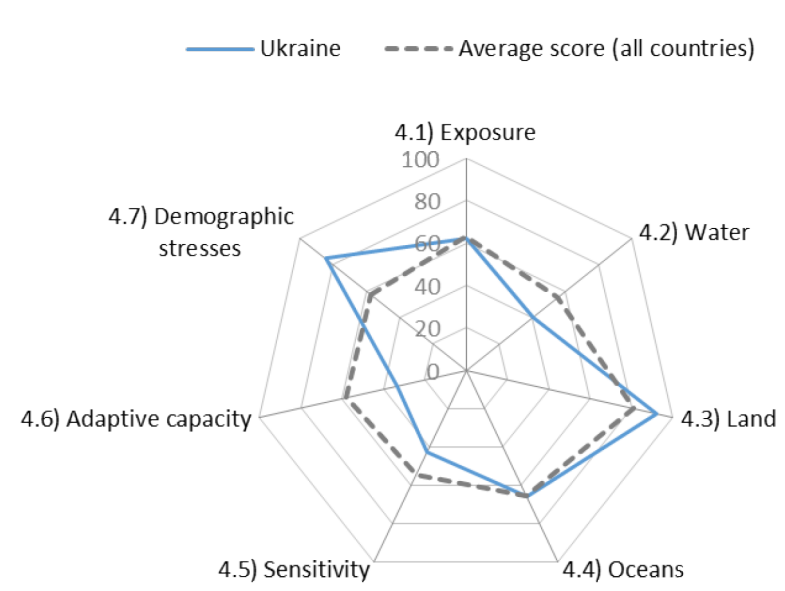

Figure 4. Estimation of natural resources of Ukraine and their level of resilience in the food security index of Ukraine for the first half of 2017

Source: Ghlobaljnyj indeks prodovoljchoji bezpeky

effective directions. Providing food to the population is a basic element of the economic, social, and political security of the state.

Based on the results obtained, the author concluded that in order to increase the level of food security of the state, it is necessary to develop its own food base, protect domestic enterprises of the agricultural sector, change 
the structure of agricultural production in accordance with market demand, and improve the quality of products of the agro-industrial complex. All this can be achieved only by combining the system of state measures using the internal reserves of the agro-industrial complex on the basis of its adaptation to the market business environment. In order to solve these problems, it is necessary: to improve the development of the import substitution system; intensify the widespread use of new technologies; promote a rational combination of large, medium, and small businesses; increase the effective interaction of the state, business, and science.

Therefore, ensuring the country's food security is the most important condition for the sovereignty, national security, social stability of the state, and its independence in international relations.

\section{References:}

Analitychna dopovidj do Shhorichnogho Poslannja Prezydenta Ukrajiny do Verkhovnoji Rady Ukrajiny «Pro vnutrishnje ta zovnishnje stanovyshhe Ukrajiny v 2017 roci» (2017). [Analytical report to the Annual Address of the President of Ukraine to the Verkhovna Rada of Ukraine "On the Internal and External Situation Ukraine in 2017]. Kyiv: NISD.

Chechel, O. M. (2000). Derzhavne reghuljuvannja zabezpechennja prodovoljchoji bezpeky [State regulation of food security]. Economy of agroindustrial complex, 8, 73-76.

Chorna knygha Kremlja. Vijna Rosiji proty Ukrajiny (2015) [The Black Book of the Kremlin. Russia's War Against Ukraine] Information based on data of central executive authorities of Ukraine. Retrieved from: http://www.ucc.ca/ wp-content/uploads/2015/02/blackbook.pdf

Derzhavna sluzhba statystyky Ukrainy [State Statistics Service of Ukraine]. Retrieved from: http://www.ukrstat.gov.ua/ Ghlobaljnyj indeks prodovoljchoji bezpeky [Global Food Security Index]. Retrieved from: http://foodsecurityindex.eiu.com/

Postanova Verkhovnoji Rady Ukrajiny Pro pryjnjattja za osnovu proektu Zakonu Ukrajiny pro prodovoljchu bezpeku Ukrajiny [Resolution of the Verkhovna Rada of Ukraine on the adoption of the draft Law of Ukraine on Food Safety of Ukraine]. Retrieved from: http://zakon.rada.gov.ua/laws/show/3498-17

Sabluk, P. T., Bilorus, O. Gh., Vlasov, V. I. (2009). Prodovoljcha bezpeka Ukrajiny [Food safety of Ukraine]. Economy of agroindustrial complex, 10, 3-7.

Paskhaver, B. J. (2014). Suchasnyj stan prodovoljchoji bezpeky [The current state of food security]. Economy of agroindustrial complex, 4, 5-12.

Teorija i praktyka dijaljnosti pidpryjemstv: monoghrafija. Innovacijyj rozvytok pidpryjemstv kharchovoji sfery ekonomiky reghionu (2017). [Theory and practice of enterprises: monograph. Innovative development of enterprises in the food industry economy region]. National metallurgist. Academy of Ukraine; per community Ed. L. M. Savchuk, L. M. Bandorina. Dnipro: Pyrogi.

Irtyscheva, I. A., Khvesyk, J. M., Stehnei, M. I. (2015). Detsentralizatsiia systemy upravlinnia v zabezpechenni staloho rozvytku silskykh terytorii [Decentralization of management system in ensuring sustainable development of rural territories]. Ekonomika $A P K, 4,64-70$.

H. Rowe, R. Mason and K. Dickel (1982). Strategic Management and Business Policy: A Methodological Approach. Reading, Massachusetts: Addison Wesley Publishing Co. Inc.

FAO (1996). Rome Declaration on World Food Security and World Food Summit Plan of Action. World Food Summit 13-17. November. Rome. 